\title{
FROM PRODUCTION TO DISCOVERY: LOOKING FOR THE SOCIAL IMPACT OF PUBLICATIONS
}

Scientific editors work from the deepest part of the discipline that we represent. We share challenges that are sometimes hard to socialize with our main clients: the authors and readers. However, in recent years we live in a way, somewhat obsessive with a common concern: the bibliometric impact of our magazines. We have been counting the number of citations, thinking that this is much more than a step that guide librarians in their policies to acquire magazines. This circumstance is favored by the evaluation systems of knowledge, especially in the Iberoamerican Scientific Space (ISS), which is dominated by the Impact Factor, an indicator of impact of the magazines that paradoxically, and contrary to the opinion of the scientists themselves, it is being used to assess objectively the quality of the articles. ${ }^{1}$ Something that can not be done objectively.

The reality is that the most competitive countries from the point of view of science and technology using different criteria. Their model is based on the social impact assessment of knowledge, but at the same time bring highest bibliometric values in their publications. The question is that what makes them forward is the impact factor or this is just a natural reflection of the different model of government of the science. In other words, what comes first: the impact factor or the relevant research? What is the cause and which is effect? The truth is that while some count the number of publications, others counts discoveries, and this is not the same.

A couple of decades there was a kind of passionate crush on the bibliometrics. ${ }^{2}$ The idea that counting citations could be reached to identify the best research trajectories was very seductive and economically, it would not be necessary to read articles to determine their level of excellence. It was enough that the authors just publish in highly cited journals (although many of them do not receive citations). The system broke the joy of many publishers, who saw significantly increase demand for posting on their journals, which ultimately resulted in an alternative model of more profitable and secure funding. No longer, those who consume the information (subscribers) have to pay, but those who produce (potential authors desperate for the need to publish and willing to afford all translations, publishing rates and even purchase their own product). Perhaps the behavior of some publishers are not becoming too edifying.

Between 2008 and 2010 some of the most influential countries in the scientific landscape, including the United States, Germany and Great Britain, looked coldly the bibliometric evaluation model and replaced the counting citations (impact factor) by an alternative model that put emphasis on the qualitative of the publicaciones. ${ }^{3}$ The quality is to be determined in a different way, emphasizing the social impact of knowledge. Today we witness the coexistence of two antagonistic models to some form of assessment of knowledge: the one that counts the number of publications and the one that recognize the discoveries. Both give different results and can be identified in various scientific and cultural spaces.

In the case of ISS, it dominates the counting of publications (publish or die), under the idea that the more you publish the more scientific impact you will have. The Brazilian case is emblematic in this regard. The CAPES, with the Qualis criteria for classifying journals, seems to send to their academics and researchers a message to publish in journals with high impact factor at any price. The same happens in Spain, where the lack of economic and political commitment to research has led to hardly bankable and poorly managed highly bureaucratic system, which researchers delegated the responsibility to produce without a solid structure that gives support to the research. ${ }^{4}$ Still, Brazil is probably one of the least harmful ISS system, because it considers magazines that have less valued and outside the most influential bibliometrical rankings. ${ }^{5}$

The concerns about the social impact is typical of more advanced systems, like the British, which evaluates the quality of the university research through the Research Assessment Exercise (RAE), system that evaluates qualitatively the four best articles of each investigator on three dimensions: outputs, impact and environment. The impact is determined based on their social, economic and cultural impact. The success of the British system has seduced other countries that have also adopted the model of case studies, such as Italy, Germany or Australia (Spain just added). In addition, it would be wise to accept that ISS countries will adopt this qualitative assessment model of discovery.

In the case of nursing, as applied science, the alternative model is much more favorable to the disciplinary interests, considering the most precious thing we have as nurses is the effects of proximity to the citizen. It is true that comparatively, the editorial nurse infrastructure is small and publications generated little scientific impact, one of the areas traditionally invisible by the great documentary resources of science. However, few disciplines have the ability to transfer nursing, whose knowledge is generated in close relationships with the patient, so that the social impact is inherent in the research act.

Seeing what is to come, it would be appropriate to start making education on emerging values in science and knowledge assessment, and the effects they will have on publications. Young talents are still in time to conduit 
the way they have to govern themselves in a scenario where competition leaves no indiscriminate accumulation of publications. It is urgent to stop teaching them how to become predators of knowledge (accurate predictors of individual performance), moving to educate in values that adorn the vocational research (which shares knowledge to provide solutions to society). We know very well all the strategies to publish in journals with impact, but now we learn about transfer, or how to make our publications count for something: to be used as guides to good practice or professional consensus documents; to affect health plans, strategic plans, health policies; even that they could be recognized by the public, are appearing in the social media highlights. The path of deception may have earned us some perks, but now it's growing reputation as authors demonstrate our position on the social activity of science.

It would be desirable that nursing leaders renounce to the abominable propensity to obedience: "yes, yes, all this is fine, but in the end what counts is what it counts," it is the phrase that I hear when I try to talk about this matter. Even though some insist on dreaming of a uniform and unambiguous Nursing, with an Anglo-Saxon court, and located on the pedestals of big science, the truth is that the vast majority of nurses continue to work, consciously or not, under the axiom that nursing as a discipline is built adhering to the natural processes of knowledge management. That is, occurring in the same language of communication with patients (which does not detract from attempts to versioning in other languages ${ }^{6}$ ), preferably using media free access to promote its universalization, addressing research problems from the plural universe in Nursing that moves like science, globalizing local knowledge (which anchored in the daily lives of each subject). In the ISS there is sufficient expression of rebellion and to ensure that this is so we can see it (Scielo and NLM resources, Cuiden and resources of the Index Foundation, among others).

In pedagogy, we need to look on the social impact of nursing as a science in order to build strong partnerships between those who take positions of leadership within the discipline (editors, academics, researchers). Only through dialogue and from a critical spirit may strengthen the position of nursing in the landscape of science and knowledge. Under the slogan "A knowledge to humanity," initiatives as DEGRA (http:/ / www.index-f.com/declaracion/), are emblematic in this sense, because in the wake of critical movements as DORA (Declaration of San Francisco), promote stance on the values that govern the promotion of the nursing knowledge. ${ }^{7}$ We invited you, to know and sign it. It is unwise to think that in the coming years, the ISS will not change. The changes come on the subject of knowledge, the guidelines will apply to all greater democracy, greater public presence and greater decision-making ability. Are we ready for this?

\author{
Manuel Amezcua \\ Doctor in Social and Health Sciences. President of the Index Foundation. Professor of the Faculty of Health Sciences of the \\ University of Granada, Spain
}

\title{
REFERENCES
}

1. Rossner M, Van Epps H, Hill E. Show me the data. J Cell Biol. 2007 Dec 17;179(6):1091-2.

2. Camí J. Impactolatría: diagnóstico y tratamiento. Med Clin. 1997; 109(13):515-24.

3. Amezcua M. Controversias en la evaluación del conocimiento: alegatos a propósito de una ciencia aplicada. Index Enferm. 2011; 20(1-2):7-11.

4. Rodríguez-Navarro A. Sound research, unimportant discoveries: research, universities, and formal evaluation of research in Spain. J Am Soc Inf Sci Technol. 2009; 60(9):1845-58.

5. Erdmann AL, Marziale MHP, Pedreira MLG, Lana FCF, Pagliuca LMF, Padilha MI, et al. Evaluation of scientific periodicals and the brazilian production of nursing articles. Rev Latino-Am Enfermagem. 2009; 17(3):403-9.

6. Padilha MI, Brüggemann O, Costa R, Silva DMGV, Vargas MA, Andrade SR, et al. Internationalization of knowledge and the enhancement of the quality and visibility of scientific brazilian journals. Text Context Enferm [online]. 2014 [acess 2015 May 25], 23(3):515-9. Disponible en: http://www.scielo.br/scielo.php?script=sci_arttext\&pid=S010407072014000300517\&lng=en\&nrm=iso\&tlng=en

7. Reina Leal LM, Amezcua M, Red Internacional de Centros Colaboradores de la Fundación Index. Comentarios a DEGRA - Declaración de Granada sobre conocimiento enfermero. Index Enferm. 2013; 22(4):246-7. 